\title{
Building literacy awareness through a community library
}

\author{
Bahagia Tarigan $^{1 *}$, Rudy Sofyan ${ }^{1}$ \\ ${ }^{1}$ Linguistics Department, Faculty of Cultural Sciences, Universitas Sumatera Utara, Medan - \\ Indonesia \\ *Email: bahagia1@usu.ac.id
}

\begin{abstract}
Every individual needs to survive and even succeed in their life. One of the ways to achieve such success is to be literate. Literacy makes people civilized and knows the purpose of their life. People need to build their awareness of the importance of literacy, one of which is through building reading literacy awareness. This paper aims at building literacy awareness through a community library built for the people in Regaji Village, Karo Regency, North Sumatra. This is a descriptive study taking the local people living in Regaji Village as the participants. Observations, interviews, and documentation were used to collect the data related to the past and current reading literacy awareness in this village. The data were analyzed qualitatively. The results of the data analysis show that the reading literacy awareness of the local people was still relatively low. However, after the presence of the community library in this village, the literacy awareness of the local people, especially children, has grown, indicated by their increased reading habits. This current situation should be maintained and developed so that all the children in this village keep aware of the importance of reading literacy that eventually helps them get success in their future life.
\end{abstract}

Keywords: Community Library, Literacy Awareness, Reading Literacy, Reading Habits.

\section{INTRODUCTION}

As one of the human rights (Lumsford, Moglen, \& Slevin, 1990; UNESCO, 2008; Becker, de Wet, $\&$ van Vollenhoven, 2015), literacy plays a very important role in helping people to survive, fulfill their basic needs, and get success in their life. In addition, positive early language and literacy development can give children a window to the world, helping children develop their potential for future success (Kupcha-Szrom, 2011). Literacy can be defined as the ability to read and write a short simple statement relating to everyday life comprehensively (UNESCO, 2008, p. 18). This idea implies that every individual has a right to get treatment helping them able to read and write, or known as acquired skills (Wildova \& Kropackova, 2015). Considering these two basic skills, reading is the skill learned earlier because it is impossible to write before having the ability to read (Rosa, 2013, p. 211). This is in line with the statement of Wildova \& Kropackova (2015), "Reading literacy is generally seen as a set of skills and abilities to use written speech for communication, entertainment, education, etc." The importance of reading is also mentioned by Koda (2005) who believes that reading is the principal method of acquiring knowledge.

Reading literacy has been mentioned in various literature. PISA (The Program for International Student Assessment) proposes a definition of reading literacy as "an individual's capacity to understand, use, and reflect on written texts, to achieve one's goals, to develop one's knowledge, and to potentially participate in society" (Organization for Economic Co-operation and Development, 2006, p. 46). This means that reading literacy refers not only to mastering the reading skill, but also the ability to work with texts, to communicate in writing, to acquire, and to process information contained in texts (Delgadova, 2015, p. 50). Meanwhile, in terms of its developmental stages, Riley (2003) argues that one of the key periods for the development of reading literacy is during a pre-literacy period ( $0-6$ years). This is corresponding to the three general phases of reading literacy proposed by Wildova \& Kropackova (2015): (1) pre-literacy period ( $0-6$ years); (2) reading literacy period (compulsory school attendance) including initial 
reading literacy period (Year 1 or Year 2 of primary school); and (3) a period of functional literacy (15 years and "more"). This means that reading literacy should begin as early as possible since children are exposed to language learning.

In this information and technology era, reading literacy is non-negotiable because reading inability results in failure in getting information and failure in life. Therefore, it is necessary to build reading literacy awareness as early as possible. However, in several places, particularly those located in villages, the local people's awareness of reading literacy is not as well-developed as in cities. People's education level and reading facilities are two of several other factors leading to such differences. As a matter of fact, all people must have equal opportunity to develop their reading literacy awareness, and the place where people live should not become the barrier. This condition will obviously affect the development of children's reading literacy.

Considering reading as an important skill in building children's reading literacy, especially in villages, the writers have made an effort by building a community library in Regaji Village, Karo Regency, North Sumatra. This village has no library outside the school context; therefore, building this community library is considered important to support the children in building their reading literacy. In relation to this community library establishment, this paper aims at building the Karonese children's reading literacy awareness through the community library that has been established.

\section{METHOD}

This study was conducted using a descriptive method. The research location was the newly established community library in Regaji Village, Karo Regency, North Sumatra. The participants were the local people living in this village. The participants were divided into two groups. The first group consisted of parents whose children were students at elementary schools or junior high schools located in this village. The second group consisted of elementary school or junior high school students. The data were collected using interviews, observations, and documentation. The interviews were conducted in order to obtain the data related to their literacy awareness; meanwhile, the observations were conducted to obtain the data related to the children's activities in the community library. The observations were conducted during weekdays within two months, from July to August of 2019. The documentation was conducted to obtain the data related to the children's activities in the community library. The data were analyzed qualitatively, describing the results of interviews and observations.

\section{DISCUSSION}

Based on the results of the observations and interviews done by the authors to the local people in Regaji Village, Karo Regency, North Sumatra, their literacy awareness was still relatively low. Most of the parents do not pay much attention to their children's reading ability development. They do ask their children to read, but rarely ask their children about the information obtained from the reading. In addition, in terms of kinds of books read by their children, most of the parents rely only on the books provided by schools or the required course books. They rarely buy other kinds of books to support their children's reading literacy development due to two main factors, i.e. education background and economic factors. Most of them are farmers with low education background and are not aware of the importance of reading literacy for their children. Besides, their low income makes them unable to buy other books in addition to the course books used at school. This is in line with Niklas, Cohrssen, and Tayler (2016, p. 1) who assert that reading literacy is closely associated with family characteristics such as socioeconomic status.

Such two factors become the main reason for building a community library in this village. The children in this village must have the right to access any information through reading regardless of their family background. They must have reading literacy since literacy is the right that every human has. The library is completed with various books, such as course books for 
elementary school students, English books, novels, comic books, short stories, puzzles, recipes, and magazines. These books are particularly intended to develop their basic reading literacy.

The library is open for all of the school-age children living in this village. They can come to the library to read whatever books they are interested in; however, they are not allowed to take the books outside the library. This policy is set out to minimize the possibility of book losses that will impact the sustainability of the library's existence.

In addition, there is a tutor provided in the library whose duties are overseeing the children's activities in the library, facilitating the information about the books provided in the library, and teaching the children to understand reading the books. The children would feel free to ask any questions to the tutor to build their reading literacy. Based on the authors' observations on the activities in the library, the children look very enthusiastic in reading the books available in the library. Enthusiasm is very important in learning because a lack of enthusiasm may have an adverse impact on student learning (Freudenberg \& Samarkovski, 2014, p. 22). Their enthusiasm is portrayed by the number of visitors to the community library daily. On average, every day the community library is visited by more than 15 children although the frequency of their visit is not stable as shown in Table 3.1.

\begin{tabular}{clc}
\hline Week & \multicolumn{1}{c}{ Date } & $\begin{array}{c}\text { Number of } \\
\text { Visitors }\end{array}$ \\
\hline $1^{\text {st }}$ & July 1-6, 2019 & 17 \\
$2^{\text {nd }}$ & July 8-13, 2019 & 15 \\
$3^{\text {rd }}$ & July 15-20, 2019 & 18 \\
$4^{\text {th }}$ & July 22-27, 2019 & 18 \\
$5^{\text {th }}$ & July 29-August 3, & 15 \\
& 2019 & \\
$6^{\text {th }}$ & August 5-10, 2019 & 16 \\
$7^{\text {th }}$ & August 12-17, 2019 & 20 \\
$8^{\text {th }}$ & August 19-24, 2019 & 20 \\
\hline
\end{tabular}

Table 3.1. The number of visitors to the community library

Based on the results of observations, supported by the documents available in the library, presented in Table 3.1, the community library is visited by at least 15 children per week. The number is the accumulation of their daily visit within a week. Although in the fifth week the number of visitors decreases compared to the number of visitors in the third and fourth weeks, this does not mean the decrease in their enthusiasm to visit the library. This is quite acceptable as they also have some excuses leading to their inability to visit the library. However, in the last two weeks of observations, the number of visitors is much higher than in the previous weeks, as 20 children regularly visit the library every week. These statistics have shown the children's great enthusiasm for visiting the community library.

Such enthusiasm is very helpful in building the children's motivation in reading. Several studies have proved the high contribution of motivation to the reading ability (Schaffner \& Schiefele, 2016; Ahmadi, 2017; Takaloo \& Ahmadi, 2017; Marsela, 2017; Turner, 2017; Ningsih \& Rosa, 2019). Turner (2017) found the importance of motivation in increasing the students' reading comprehension. This is in line with the statement of Ningsih and Rosa (2019) who argue that the higher the motivation the students have, the more easily they understand their readings. Therefore, enthusiasm and motivation positively influence the children's achievement in reading.I

The reading enthusiasm and motivation grow and increase the students' reading habits. The students' increased reading habit is seen from their persistent and extensive reading in the library. In the early opening of the library, most of the books read by the children were comic books and puzzles written in bahasa Indonesia. The reason why comic books and puzzles are available in the library is to grow the children's interest in reading because children like pictures and fiction. They do not like books full of words. This is in line with Chettri (2013) who states that reading interest 
refers to the selection of subject matter or preference for a genre of literature being read. This idea strengthens the role of certain kinds of books in building children's reading habits. When their interest in reading is grown, they start to read other kinds of books, and when they want to read various kinds of books, their reading habit starts to grow. This is the current picture of the community library where the children do not only read comic books and puzzles but also read other kinds of books available in the library such as short stories, English books, magazines, dictionaries, and so forth (see Table 3.2). This supports Erdem's (2015) argument that reading habits can be seen from various kinds of books read and the time spent on reading by the students.

\begin{tabular}{clc}
\hline Week & \multicolumn{1}{c}{ Date } & Kinds of books \\
\hline $1^{\text {st }}$ & July 1-6, 2019 & Comic books, Puzzles \\
$2^{\text {nd }}$ & July 8-13, 2019 & Comic books, Puzzles \\
$3^{\text {rd }}$ & July 15-20, 2019 & Comic books, Puzzles, Short stories \\
$4^{\text {th }}$ & July 22-27, 2019 & Comic books, English books, Short \\
& & stories \\
$5^{\text {th }}$ & July 29-August 3, 2019 & Comic books, Puzzles, Short stories \\
$6^{\text {th }}$ & August 5-10, 2019 & Comic books, Short stories, \\
& & Magazines \\
$7^{\text {th }}$ & August 12-17, 2019 & Comic books, English books, \\
$8^{\text {th }}$ & August 19-24, 2019 & Dictionaries, Magazines \\
& & Comic books, Puzzles, Short stories, \\
& & English books, Magazines, \\
\end{tabular}

The results of observations and documentation displayed in Table 3.2 show that in the first two weeks of the opening of the community library, the children only read comic books and puzzles. However, in the weeks after, they read more kinds of books. Even during the eighth week, they read all kinds of books available in the library including comic books, puzzles, short stories, English books, and magazines. Moreover, based on the results of the interviews, the children want to read some other kinds of books, such as encyclopedias and content books. However, those books are not yet available in the community library. In addition, the number of copies of the same book is also limited.

As elaborated in the previous paragraph, the reading habit does not come automatically; instead, it takes time to develop (Bendriss \& Golkowska, 2011, p. 39). However, once it has developed, it helps children developing their literacy awareness. This supports Bendriss and Golkowska (2011) who argue that reading habits give positive impacts on students' reading literacy. The children are now aware of the importance of reading in their life. They get a lot of information that is impossible to be obtained simply from their course books at school. Having reading literacy awareness is a good capital for the children to pursue their careers (Lyon, 2002; Fawcett, 2003). They now feel that reading is part of their daily activities. Based on the data obtained from the library diary, many children visit the library every weekday. This means that their reading literacy has developed, and they never want to escape reading from their daily routines. Besides, this also means that having reading literacy awareness makes the children often choose to read regularly outside of school (Krashen, 1996; Clark \& Hawkins, 2011).

Building reading literacy awareness since an early age is a very good policy because it is easier to build children's attitudes towards reading during their childhood. This idea supports Bendriss and Golkowska (2011, p. 53) who believe that reading habit is important and needs to be supported as early as possible. The idea of building reading literacy awareness at an early age is also mentioned by Bennett, Martin, \& Weigel (2002) who emphasize on family contributions during early age in children's reading acquisition. In contrast, parents who are not sufficiently involved in their children's education, in this case reading literacy, indirectly demotivate their 
children, negatively impacting their children's academic achievement. The importance of building reading literacy awareness since an early age is also mentioned by Niklas et al. (2016) the age at which children learn to read for the first time is highly correlated with their reading frequency in the year before they go to school.

Moreover, the role of a tutor in this community library cannot be underestimated. Her role is significant in building children's reading literacy awareness. She actively motivates the children and assists every child not only in gaining more insights but also in teaching some of them to read fluently. This is because some of the children who come to the library are not yet able to read fluently although they have entered an elementary school. Reading inability is the main indicator of illiteracy (Musen, 2010). Therefore, the presence of a tutor in this community library partially helps the tasks of teachers at formal schools in guiding the children in learning to read.

\section{CONCLUSIONS}

Based on the discussion on building reading literacy awareness elaborated above, it is concluded that the community library is very helpful for the children in Regaji Village, Karo Regency, North Sumatra in building their reading literacy awareness. This can be seen from the increasing number of children visiting the library in the last two weeks of observations. In addition, the more variety of books read by children every week also becomes the sign that their reading literacy awareness has been developed.

Low education background and economic factors that, so far, become the hindrance of the local people to acquire reading literacy have partially been solved due to the existence of this community library. However, the library still lacks book collection, and this probably will decrease the students' reading habits. They will feel bored if they do not find new books to read. This is a challenge not only for the authors but also for those who concern with the development of children reading literacy awareness in this village.

Referring to the conclusions that have been elaborated, it is suggested for the local government and education observers to find the sources of adding the collection of books in this community library. In addition to the number of book collections, this library also lacks the number of copies of the same book.

The library has been founded, and it is the responsibility of all local people and local governments to maintain it to continue making Karonese people always aware of the importance of reading literacy to the successful lives of the next generation.

\section{ACKNOWLEDGMENTS}

The authors would like to thank the Community Service Institute of Universitas Sumatera Utara for funding this community service project under the Program Pengabdian Kepada Masyarakat Mono Tahun TALENTA 2019 Grant.

\section{REFERENCES}

Ahmadi, M. R. 2017. The Impact of Motivation on Reading Comprehension. International Journal of Research in English Education, 2(1), 1-7.

Becker, A., de Wet, A., \& van Vollenhoven, W. 2015. Human rights literacy: Moving towards rights-based education and transformative action through understandings of dignity, equality, and freedom. South African Journal of Education, 35(2), 1-12.

Bendriss, R. \& Golkowska, K. 2011. Early reading habits and their impact on the reading literacy of Qatari undergraduate students. Arab World English Journal, 2(4), 37-57. 
Bennett, K. K., Martin, S. S., \& Weigel, D. J. 2002. Children"s acquisition of early skills: Examining family contributions. Early Childhood Research Quarterly, 17, 295-317.

Chettri, K. 2013. Reading habits - An overview. IOSR Journal of Humanities and Social Science, 14(6), 13-17.

Clark, C. \& Hawkins, L. 2011. Public Libraries and Literacy: Young people's reading habits and attitudes to public libraries, and an exploration of the relationship between public library use and school attainment. London: National Literacy Trust

Delgadova, E. 2015. Reading literacy as one of the most significant academic competencies for the university students. Procedia - Social and Behavioral Sciences, 178, 48-53.

Erdem, A. 2015. A research on reading habits of university students: (Sample of Ankara University and Erciyes University). Procedia - Social and Behavioral Sciences, 174 39833990.

Fawcett, A. J. 2003. The international adult literacy survey in Britain: Impact on policy and practice. Dyslexia, 9, 99-121.

Freudenberg, B. \& Samarkovski, L. 2014. Enthusiasm and the effective modern academic. Australian Universities' Review, 56(1), 22-31.

Koda, K. 2005. Insights into second language reading: A cross-linguistic approach. Cambridge: Cambridge University Press.

Krashen, D. 1996. Comic book reading, enjoyment and pleasure reading among middle school students. Journal of Reading Improvement, 53(1), 51-54.

Kupcha-Szrom, J. 2011. A window to the world: Early language and literacy development. Washington, DC: ZERO TO THREE.

Lumsford, A. A., Moglen, H., \& Slevin, J. 1990. The right to literacy. New York: The Modern Language Association of America.

Lyon, G. R. 2002. Reading development, reading difficulties, and reading instruction educational and public health issues. Journal of School Psychology, 40, 3-6.

Marsela, S. 2017. The correlation between reading motivation and reading comprehension achievement of the eleventh-grade students of MAN 2 Palembang (Unpublished Thesis). Palembang: Universitas Islam Raden Fatah.

Musen, L. 2010. Early Reading Proficiency. New York: Brown University.

Niklas, F., Cohrssen, C., \& Tayler, C. 2016. The sooner, the better: early reading to children. SAGE Open, 6(4), 1-11.

Ningsih, P. \& Rosa, R. N. 2019. The use of pairs check strategy in teaching reading comprehension on narrative text to junior high school students. Journal of English Language Teaching, 8(1), 1-12. 
Organization for Economic Co-operation and Development. 2006. Assessing scientific, reading and mathematical literacy: A framework for PISA 2006. Paris: OECD Publications.

Riley, J. 2003. The teaching of reading: The development of literacy in the early years. London, New York: McGraw-Hill.

Rosa, R. N. 2013. Introduction to linguistics. Padang: Sukabina Press.

Schaffner, E. \& Schiefele, U. 2016. The contributions of intrinsic and extrinsic reading motivation to the development of reading competence over summer vacation. Reading Psychology, 37, 917-941.

Takaloo, N. M. \& Ahmadi, M. R. 2017. The effect of learners' motivation on their reading comprehension skill: A literature review. International Journal of Research in English Education, 2(3), 10-21.

Turner, D. S. 2017. Reading motivation: Using extrinsic incentives as a motivational tool (Unpublished Dissertation). Jefferson City: Carson-Newman University.

UNESCO Institute for Statistics. 2008. International literacy statistics: A review of concepts, methodology, and current data. Montreal: UNESCO Institute for Statistics.

Wildova, R. \& Kropackova, J. 2015. Early childhood pre-reading literacy development. Procedia Social and Behavioral Sciences, 191, $878-883$ 